\title{
Effect of calcium supplementation on milk production and hypocalcaemia
}

\author{
S. F. LEDGARD ${ }^{1}$, G. D. PITMAN ${ }^{2}$ and J. D. MORTON ${ }^{3}$ \\ ${ }^{1}$ AgResearch, Ruakura Research Centre, PB 3123, Hamilton \\ ${ }^{2}$ Wrightson Solutions, P.O. Box 440, Hawera \\ ${ }^{3}$ AgResearch, Invermay Agricultural Centre, PB 50034, Mosgiel \\ stewart.ledgard@agresearch.co.nz
}

\begin{abstract}
A dairy farmlet trial carried out in Central Taranaki in $1999 / 2000$ and 2000/2001 examined the effects of calcium (Ca) supplementation (110-180 g/cow of fine limeflour drenched daily between calving in August and mid-mating in December) on serum Ca, incidence of milk fever and milksolids (MS) production at stocking rates of 2.5, 3.2, 3.7 and 4.2 Jersey cows/ha. Pasture $\mathrm{Ca}$ contents in spring were around $0.4 \%$ in both years and in the marginal to adequate range for dairy cow requirements. However, average blood serum $\mathrm{Ca}$ concentrations of $2.4 \mathrm{mmol} / \mathrm{l}$ were moderate and only $5 \%$ of non-Ca-treated cows occasionally had serum $\mathrm{Ca}$ less than $2 \mathrm{mmol} / \mathrm{l}$, within the range for sub-clinical hypocalcaemia. Incidence of clinical milk fever was negligible (0-1\%) in milking cows, with no treatment differences. There was no significant effect of $\mathrm{Ca}$ supplementation on MS production, although there was a consistent trend (all farmlets in both years) for a small response (3-4\%) at the first herd testing.
\end{abstract}

Keywords: calcium supplementation, dairy cow reproduction, dairy cows, hypocalcaemia, milksolids production

\section{Introduction}

Metabolic disorders such as hypocalcaemia (milk fever) and hypomagnesaemia (grass staggers) are important animal health issues in the New Zealand dairy industry that have multifactorial causes. The incidence of clinical hypocalcaemia has been estimated to be $2 \%$ (McDougall 2001).

Increased dairy cow stocking rates and milksolids (MS) production during the past decade may also have increased the potential for metabolic disorders. Block
(1984) and Beede et al. (1992) measured increases in milk production of approximately 14 and $7 \%$ by preventing clinical and sub-clinical hypocalcaemia respectively through supplementing with calcium $(\mathrm{Ca})$. In contrast, Roche et al. (2003) reported no significant effect of $\mathrm{Ca}$ supplementation on milk production. $\mathrm{Ca}$ supplementation (e.g. lime flour) is being used increasingly in spring to improve blood serum Ca status and to overcome any possible clinical and sub-clinical hypocalcaemia. Sub-clinical hypocalcaemia is thought to result in depressed cow appetite, feed intake and milk production. In addition it may reduce cow reproductive performance (Stevenson et al. 1999).

An opportunity existed to examine the effects of $\mathrm{Ca}$ supplementation on hypocalcaemia and milk production within a farmlet trial at the Stratford Demonstration Farm that commenced in winter 1998 . The farm typically has a relatively high incidence of post-calving hypocalcaemia. This experiment examined the effects of supplementing one-half of the cows in each farmlet with $\mathrm{Ca}$ between calving and mid-mating, on milk production and cow reproductive performance over a two year period.

\section{Materials and methods \\ Management}

A grazing trial at the Stratford Demonstration Farm commenced in June 1998 with treatments as shown in Table 1. The farm is located on the eastern boundary of Stratford on a Stratford sandy loam (Allophanic soil). The site is $310 \mathrm{~m}$ above sea level and receives about $2050 \mathrm{~mm}$ rainfall annually.

All farmlets received $146 \mathrm{~kg} \mathrm{~N} / \mathrm{ha} / \mathrm{yr}$ in split applications. Inputs of phosphorus (P) and potassium (K) were 45 and $100 \mathrm{~kg} / \mathrm{ha} /$ year, respectively, with split

Table 1 Farmlet size, stocking rate, cow liveweight and condition score.

\begin{tabular}{|c|c|c|c|c|c|c|c|c|}
\hline \multirow[t]{2}{*}{ Farmlet } & \multirow[t]{2}{*}{$\begin{array}{l}\text { Stocking } \\
\text { rate } \\
\text { (cows/ha) }\end{array}$} & \multirow[t]{2}{*}{$\begin{array}{l}\text { Comparative } \\
\text { stocking rate } \\
\text { (kg LW/t DM) }\end{array}$} & \multicolumn{2}{|c|}{$\begin{array}{c}\text { Cow } \\
\text { - liveweight - } \\
(\mathrm{kg})\end{array}$} & \multicolumn{2}{|c|}{$\begin{array}{c}\text { Cow } \\
\text { - condition - } \\
\text { score }\end{array}$} & \multirow[t]{2}{*}{$\begin{array}{l}\text { Farmlet } \\
\text { size } \\
\text { (ha) }\end{array}$} & \multirow[t]{2}{*}{$\begin{array}{l}\text { Herd } \\
\text { size } \\
\text { (cows) }\end{array}$} \\
\hline & & & $\begin{array}{c}\text { July } \\
1999\end{array}$ & $\begin{array}{l}\text { July } \\
2000\end{array}$ & $\begin{array}{c}\text { July } \\
1999\end{array}$ & $\begin{array}{c}\text { July } \\
2000\end{array}$ & & \\
\hline 1 & 2.5 & 66 & 425 & 407 & 5.2 & 5.2 & 13.5 & 34 \\
\hline 2 & 3.2 & 82 & 403 & 405 & 5.1 & 4.8 & 12.6 & 40 \\
\hline 3 & 3.7 & 98 & 374 & 385 & 4.9 & 4.8 & 10.8 & 40 \\
\hline 4 & 4.2 & 110 & 396 & 386 & 5.1 & 4.6 & 9.5 & 40 \\
\hline
\end{tabular}


Figure 1 Average $\mathrm{Ca}$ and $\mathrm{Mg}$ contents of pasture over time.
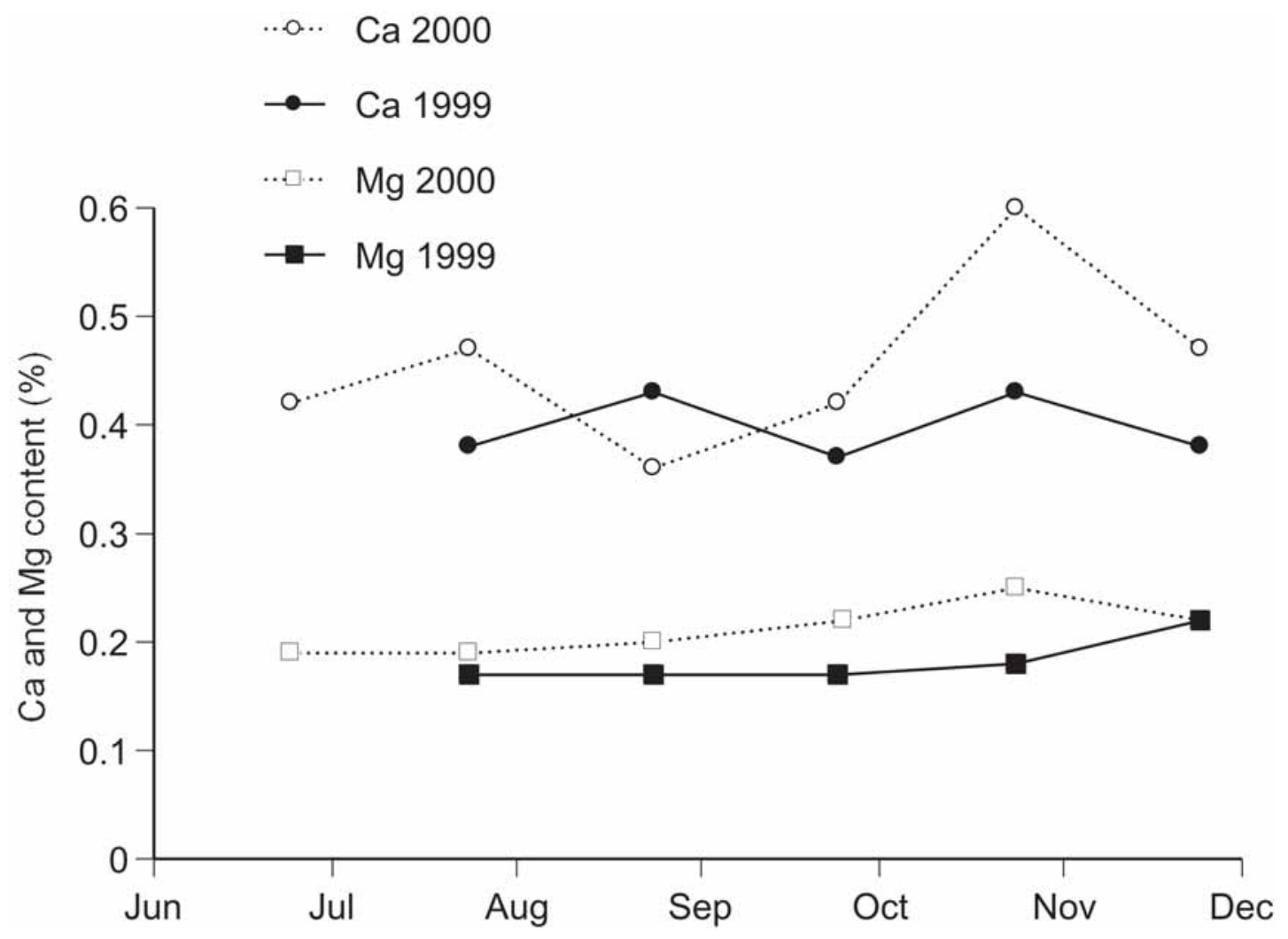

Table 2 Effect of Ca supplementation on serum Ca and Mg concentrations during 1999 and 2000. All data was covariate-adjusted for values measured at the sampling on 15 July (prior to Ca supplementation).

\begin{tabular}{|c|c|c|c|c|c|}
\hline & & \multicolumn{2}{|c|}{$\mathrm{Ca}$} & \multicolumn{2}{|c|}{$\mathrm{Mg}$} \\
\hline & & 1999 & 2000 & 1999 & 2000 \\
\hline \multicolumn{6}{|c|}{ 5-10 days post-calving } \\
\hline & Nil & - & 2.50 & - & 0.64 \\
\hline & $+\mathrm{Ca}$ & - & 2.41 & - & 0.74 \\
\hline & SED & & 0.05 & & $0.05^{\star}$ \\
\hline \multicolumn{6}{|l|}{ September } \\
\hline & Nil & 2.27 & 2.50 & 0.68 & 0.85 \\
\hline & $+\mathrm{Ca}$ & 2.38 & 2.51 & 0.69 & 0.90 \\
\hline & SED & $0.06^{*}$ & 0.04 & 0.04 & 0.03 \\
\hline \multicolumn{6}{|l|}{ November } \\
\hline & Nil & 2.40 & 2.37 & 0.68 & 0.75 \\
\hline & $+\mathrm{Ca}$ & 2.53 & 2.41 & 0.61 & 0.84 \\
\hline & SED & $0.04^{* *}$ & 0.04 & 0.05 & 0.08 \\
\hline \multicolumn{6}{|l|}{ February } \\
\hline & Nil & 2.40 & 2.59 & 0.82 & 0.92 \\
\hline & $+\mathrm{Ca}$ & 2.39 & 2.56 & 0.87 & 0.92 \\
\hline & SED & 0.04 & 0.04 & 0.04 & 0.04 \\
\hline
\end{tabular}

${ }^{\star} P<0.05 ;{ }^{* *} P<0.01$ 
applications in September/October and March. Lime had been applied to one-half of the paddocks in each farmlet during the previous 3 years. Average soil test values (AgResearch Quick Test units) for the Stratford Demonstration Farm in recent years were $\mathrm{pH} 5.8 \mu \mathrm{g} / \mathrm{ml}$, Olsen P 33, K 6, Ca 5, magnesium (Mg) 11 and sulphate-sulphur $12 \mu \mathrm{g} / \mathrm{g}$.

\section{Calcium treatment}

In July 1999 and 2000, half of the cows within each herd were randomly allocated to nil or $+\mathrm{Ca}$ treatments so that average cow age, body condition score and live weight, cow Breeding Worth and calving date and spread were similar between treatments. Calving commenced on 1 August in both years. Treated cows received $50 \mathrm{~g} \mathrm{Ca}$ ( $150 \mathrm{ml}$ Nova-Cal per cow, which is a mixture of $\mathrm{CaCl}_{2}$ and hydrated lime flour of $2.5 \mathrm{~mm}$ particle size) as soon as possible after calving in the first year, and during the entire colostrum period (4 days) in the second year. Thereafter, the $+\mathrm{Ca}$ cows were drenched once per day with a suspension of fine lime flour (Omya-Cal, c. 10 $\mathrm{mm}$ average particle size) at 110-180 $\mathrm{g}(40-70 \mathrm{~g} \mathrm{Ca} /$ cow), depending on pasture supply and pasture $\mathrm{Ca}$ status (target $1 \%$ of diet $\mathrm{DM}$ as $\mathrm{Ca}$ ). The highest $\mathrm{Ca}$ levels in drench were administered in September, and were least from October until drenching ceased on 7 December 1999 and 6 December 2000. The nil Ca treatment cows received no supplemental Ca, except for the few which had clinical hypocalcaemia and received a single intravenous injection or a single oral $\mathrm{Ca}$ supplementation to avoid death, as per standard farm treatment for downer cows.

Drenching with $\mathrm{Ca}$ occurred at evening milkings. At the morning milkings, all cows were drenched with magnesium oxide $(\mathrm{MgO})$ at $25 \mathrm{~g} / \mathrm{cow} /$ day between calving and mid-October to overcome possible $\mathrm{Mg}$ deficiency. $\mathrm{MgO}$ at $50 \mathrm{~g} / \mathrm{cow} /$ day was also dusted onto pasture for 4 weeks pre-calving, and a light rate of magnesium chloride $\left(\mathrm{MgCl}_{2}\right)$ was administered through the stock water supply system over the period.

\section{Animal measurements}

Five cows from each $\mathrm{Ca}$ treatment, across all stocking rates (i.e. 40 cows in total) were blood sampled in midJuly (prior to Ca supplementation), mid-September, mid-November and mid-February for analysis of $\mathrm{Ca}$ and $\mathrm{Mg}$ status. The post-calving data was covariateadjusted for values measured pre-calving on 15 July. In the second year, an additional sampling was made 5-10 days post-calving. Records were kept of the incidence of clinical milk fever and of reproductive performance in all nil and $+\mathrm{Ca}$ herds. The latter included numbers of cows mated at 3, 4 and 6 weeks after commencing mating, and numbers empty after pregnancy testing. Fortnightly herd testing of all cows was used to calculate MS production over time. This was statistically analysed using the REML procedure of Genstat.

\section{Pasture $\mathrm{Ca}$ and $\mathrm{Mg}$}

Monthly pasture samples were collected from two pregrazing paddocks in each farmlet and analysed for $\mathrm{Ca}$ and $\mathrm{Mg}$. Pasture intake by cows was estimated from calibrated visual assessment of pre- and post-grazing pasture mass.

\section{Results \\ Pasture $\mathrm{Ca}$ and $\mathrm{Mg}$}

The $\mathrm{Ca}$ concentration of pasture showed no clear temporal trend in 1999 (Figure 1) and averaged 0.39\%, with no significant effect of stocking rate. In 2000, Ca concentrations were constant at about $0.4 \%$ until lateNovember when they increased significantly. Pasture $\mathrm{Mg}$ was constant at $0.17 \%$ in 1999 and $0.2 \%$ in 2000 (i.e. around the adequate level for cow requirements of $0.2 \%$ from Cornforth \& Sinclair (1984)) but showed a small increase at the last samplings in each year.

\section{Blood serum Ca and $\mathrm{Mg}$ concentrations}

The average blood serum $\mathrm{Ca}$ concentrations in the control untreated herds were 2.35 and $2.49 \mathrm{mmol} / 1$ in 1999 and 2000, respectively (Table 2). In the control herds there were only three occasions when serum $\mathrm{Ca}$ concentration for an individual cow was below the critical concentration for sub-clinical hypocalcaemia of $2.0 \mathrm{mmol} / 1$ (e.g. Thilsing-Hansen \& Jorgensen 2001). These were September 1999, 5-10 days post-calving in 2000 and September 2000. None were below $1.8 \mathrm{mmol} /$ 1.

In 1999, there was a significant increase in serum Ca concentration in the Ca-supplemented cows at the September and November samplings, but not at the February sampling. There was no significant effect of $\mathrm{Ca}$ supplementation on serum $\mathrm{Mg}$ concentration. In the second year, there was no significant effect of $\mathrm{Ca}$ supplementation on serum $\mathrm{Ca}$ levels or on other nutrients except for a significantly higher $\mathrm{Mg}$ level at the first sampling. Serum Mg concentrations were above the minimum for response to supplementation of 0.6 $\mathrm{mmol} / \mathrm{l}$ (Grace 1983) throughout the study, but were relatively low $(<0.7 \mathrm{mmol} / \mathrm{l})$ in September and November 1999 and at 5-10 days post-calving in 2000.

\section{Incidence of milk fever}

There was no clear difference between treatments in incidence of clinical milk fever. There was a trend for greater incidence of milk fever in $+\mathrm{Ca}$ treatments in the first year and there were no milk fever cases in milking cows at all in the second year (Table 3). Most milk fever 
Table 3 Number of cows requiring treatment for clinical milk fever.

\begin{tabular}{|c|c|c|c|c|c|c|}
\hline & \multicolumn{2}{|c|}{ Pre-calving or calving ${ }^{1}$} & \multicolumn{2}{|c|}{ Milking cows } & \multicolumn{2}{|c|}{ - Total } \\
\hline & Nil & $+\mathrm{Ca}$ & Nil & $+\mathrm{Ca}$ & Nil & $+\mathrm{Ca}$ \\
\hline \multicolumn{7}{|l|}{ 1999: } \\
\hline Total $^{2}$ & 1 & 5 & 0 & 2 & 1 & 7 \\
\hline \multicolumn{7}{|l|}{ 2000: } \\
\hline Total $^{2}$ & 14 & 3 & 0 & 0 & 14 & 3 \\
\hline
\end{tabular}

Table 4a First year MS production ( $\mathrm{kg} / \mathrm{cow}$ ) for the first herd testing, and cumulatively up to the end of Ca supplementation on 7 December 1999 and for the whole lactation, as affected by Ca supplementation.

\begin{tabular}{|c|c|c|c|c|c|c|}
\hline & \multicolumn{2}{|c|}{$\begin{array}{c}\text { MS/cow/day } \\
\text { Initial sampling }\end{array}$} & \multicolumn{2}{|c|}{$\begin{array}{l}\mathrm{MS} / \mathrm{cow}- \\
\text { Calving to } 7 \mathrm{Dec} .\end{array}$} & \multicolumn{2}{|c|}{$\begin{array}{l}\mathrm{MS} / \mathrm{cow}- \\
\text { Whole lactation }\end{array}$} \\
\hline & Nil & $+\mathrm{Ca}$ & Nil & $+\mathrm{Ca}$ & Nil & $+\mathrm{Ca}$ \\
\hline Farmlet avera & 1.27 & 1.32 & 178.5 & 179.4 & 340.2 & 340.0 \\
\hline SED & \multicolumn{2}{|c|}{0.03} & \multicolumn{2}{|c|}{3.1} & \multicolumn{2}{|c|}{6.0} \\
\hline $2.5 \mathrm{cows} / \mathrm{ha}$ & 1.47 & 1.57 & 196 & 196 & 385 & 383 \\
\hline $3.2 \mathrm{cows} / \mathrm{ha}$ & 1.26 & 1.27 & 180 & 176 & 365 & 355 \\
\hline $3.7 \mathrm{cows} / \mathrm{ha}$ & 1.24 & 1.27 & 171 & 171 & 316 & 320 \\
\hline $4.1 \mathrm{cows} / \mathrm{ha}$ & 1.12 & 1.16 & 167 & 175 & 292 & 304 \\
\hline SED & \multicolumn{2}{|c|}{0.07} & \multicolumn{2}{|c|}{6.0} & \multicolumn{2}{|c|}{11} \\
\hline
\end{tabular}

Table $4 \mathbf{b}$ Second year MS production (kg/cow) for the first herd testing, and cumulatively up to the end of Ca supplementation on 6 December 2000 and for the whole lactation, as affected by Ca supplementation.

\begin{tabular}{|c|c|c|c|c|c|c|}
\hline & \multicolumn{2}{|c|}{$\begin{array}{c}\text { MS/cow/day } \\
\text { Initial sampling }\end{array}$} & \multicolumn{2}{|c|}{$\begin{array}{l}-\mathrm{MS} / \mathrm{cow}- \\
\text { Calving to } 6 \mathrm{Dec} .\end{array}$} & \multicolumn{2}{|c|}{$\begin{array}{l}-\mathrm{MS} / \mathrm{cow}- \\
\text { Whole lactation }\end{array}$} \\
\hline & Nil & $+\mathrm{Ca}$ & Nil & $+\mathrm{Ca}$ & Nil & $+\mathrm{Ca}$ \\
\hline Farmlet average & 1.50 & 1.55 & 173.4 & 176.2 & 341.8 & 343.6 \\
\hline SED & \multicolumn{2}{|c|}{0.03} & \multicolumn{2}{|c|}{2.6} & \multicolumn{2}{|c|}{5.2} \\
\hline $2.5 \mathrm{cows} / \mathrm{ha}$ & 1.65 & 1.72 & 184 & 192 & 362 & 372 \\
\hline $3.2 \mathrm{cows} / \mathrm{ha}$ & 1.55 & 1.65 & 181 & 178 & 356 & 345 \\
\hline $3.7 \mathrm{cows} / \mathrm{ha}$ & 1.43 & 1.46 & 168 & 173 & 328 & 335 \\
\hline $4.1 \mathrm{cows} / \mathrm{ha}$ & 1.37 & 1.39 & 161 & 162 & 321 & 322 \\
\hline SED & \multicolumn{2}{|c|}{0.07} & \multicolumn{2}{|c|}{5.3} & \multicolumn{2}{|c|}{10} \\
\hline
\end{tabular}

cases occurred pre-calving or during calving, which was generally prior to any $\mathrm{Ca}$ treatment.

\section{Cow reproduction}

There was no significant effect of Ca supplementation or stocking rate on cow reproductive performance (data not presented). However, low cow numbers made it difficult to achieve a statistical difference.

\section{Milksolids production}

There was no significant effect of $\mathrm{Ca}$ supplementation on MS production throughout the 1999 and 2000 milking seasons (Tables $4 \mathrm{a}$ and $4 \mathrm{~b}$ ). However, there was a trend for a small positive non-significant response in milk production to $\mathrm{Ca}$ at the first sampling at all stocking rates in both years. Per cow MS production decreased with increasing stocking rate (Table $4 \mathrm{a}, \mathrm{b}$ ).

\section{Discussion}

The lack of a significant effect of Ca supplementation on MS production despite a consistent trend for a small response at the first herd testing was similar to the findings of Roche et al. (2003). Stevenson et al. (1999) also observed no significant increase in MS production when cows in 6 commercial herds were drenched with calcium chloride $\left(\mathrm{CaCl}_{2}\right)$ twice within two days of 
calving. This trend was most evident at the highest stocking rate in the first year and at the lowest stocking rate in the second year. Pasture intake per cow was least in the $4.2 \mathrm{cows} / \mathrm{ha}$ farmlet and therefore these cows would have had the lowest intake of $\mathrm{Ca}$ from pasture. However, they were also the lightest and thinnest cows ( $391 \mathrm{~kg}, 4.8 \mathrm{CS}$ vs $416 \mathrm{~kg}, 5.2 \mathrm{CS}$ pre-calving at 4.2 and $2.5 \mathrm{cows} / \mathrm{ha}$, respectively) and produced the least milk post-calving (11.6 v 15.3 litres/cow at the first herd test, respectively). Incidence of hypocalcaemia is likely to be influenced by the relativity of Ca supply in feed and $\mathrm{Ca}$ output in milk. Various studies have shown that the period of highest demand for $\mathrm{Ca}$ is around calving when the foetus is at peak growth and post-calving when output in milk is high, particularly for the first milk (colostrum) which has a higher $\mathrm{Ca}$ concentration than milk from other times of year (e.g. Shappell et al. 1987).

Detailed evaluation of small responses to $\mathrm{Ca}$ supplementation would have required a larger number of cows. In 1999 there was higher pasture growth in October compared to an average year and a higher clover content of pastures was observed. The winter/spring of 2000 was also relatively dry with pasture growth which was higher than average, except during late-September and early-October. The general incidence of milk fever was lower in 1999 and 2000 than in previous years on this farm and anecdotally in the district.

Pasture Ca contents were in the marginal to adequate range for cow requirements of $0.35-0.44 \%$ (Grace 1983). These were similar to the $\mathrm{Ca}$ concentrations measured in previous years and suggest that factors other than pasture $\mathrm{Ca}$ content are more critical determinants of incidence of milk fever.

Low Mg status can impact on hypocalcaemia through reduced parathyroid hormone production which causes reduced resorption of bone Ca (Fontenot et al. 1989). However, because of daily $\mathrm{Mg}$ supplementation and the marginally adequate blood and pasture $\mathrm{Mg}$ levels measured, there should have been no effect of animal $\mathrm{Mg}$ status on availability of $\mathrm{Ca}$ to the cows.

Mean blood serum Ca levels were above the critical value of $2.0 \mathrm{mmol} / \mathrm{l}$ for subclinical hypocalcaemia (e.g. Thilsing-Hansen \& Jorgensen 2001), with an average of $2.4 \mathrm{mmol} / 1$. In the study of six herds by Stevenson et al. (1999), about $20 \%$ of the untreated cows had serum Ca below $2.0 \mathrm{mmol} / 1$. Stevenson et al. (1999) observed minimal increase in the serum $\mathrm{Ca}$ concentrations of cows treated for two days after calving relative to untreated cows. However, the timing of blood sampling after $\mathrm{Ca}$ administration can be important. Queen et al. (1993) measured increased serum $\mathrm{Ca}$ at 24-48 hours after $\mathrm{CaCl}_{2}$ drenching, but there were no significant differences thereafter. In the present study, prolonged drenching with fine limeflour increased serum Ca levels by $0.12 \mathrm{mmol} /$ litre $(+5 \%)$ during the drenching period in year one only. However the usefulness of the serum $\mathrm{Ca}$ measurements was limited by the lack of sampling in the period immediately post-calving.

\section{Conclusions}

Results from this trial are inconclusive about the benefits of $\mathrm{Ca}$ supplementation on milk production and milk fever, although there was a trend for a small initial response in milk production. Detection of small significant differences would have required greater cow numbers and covariate data. Incidence of milk fever was less than in previous years, possibly due to greater pasture growth than average, and may have limited potential responsiveness to $\mathrm{Ca}$. Pasture $\mathrm{Ca}$ contents were in the marginal-to-adequate range, whereas blood serum $\mathrm{Ca}$ was slightly above critical levels, indicating adequate $\mathrm{Ca}$ status of cows during both years of the study.

\section{ACKNOWLEDGEMENTS}

We are grateful to FertResearch for funding this study. We also thank Bernard Novak for supply of Omya-Cal lime flour. Skilful farm management by John and Clare Thompson and Gary and Tracey Commerer is acknowledged, as well as Stratford District Veterinary Services for blood sampling, and John Waller for statistical analysis of data.

\section{REFERENCES}

Beede, D.K.; Sanchez, W.K.; Wang, C. 1992. Macrominerals. pp. 272-286 In: Large dairy herd management. Eds. Van Horn, H.H; Wilcox, C.J. University of Florida, Gainesville, Florida, USA.

Block, E. 1984. Manipulating dietary anions and cations for prepartum dairy cows to reduce incidence of milk fever. Journal of Dairy Science 67: 2939-2948.

Cornforth, I.S.; Sinclair, A.G. 1984. Fertiliser recommendations for pastures and crops in New Zealand. New Zealand Ministry of Agriculture and Fisheries, Wellington. 78 pp.

Fontenot, J.P.; Allen, V.G.; Bunce, G.E.; Goff, J.P. 1989. Factors influencing magnesium absorption and metabolism in ruminants. Journal of Animal Science 67: 3445-3455.

Grace, N.D. 1983. The mineral requirements of grazing ruminants. New Zealand Society of Animal Production, Occasional Publication No. 9. 150pp.

McDougall, S. 2001. Effects of periparturient diseases and conditions on the reproductive performance of New Zealand dairy cows. New Zealand Veterinary Journal 49: 60-67.

Queen, W. G.; Miller, G. Y.; Masterson, M. A. 1993. Effects of oral administration of calcium-containing 
gel on serum concentration in postparturient dairy cows. Journal of the American Veterinary Medical Association 202: 607-609.

Roche, J.R.; Dalley, D.E.; Moate, P.; Math, M. 2003. Variations in the dietary cation-anion difference and acid-base balance of dairy cows on a pasture-based diet in south-eastern Australia. Journal of Dairy Science 86: 2658-2666.

Shappell, N.W.; Herbein, J.H.; Deftos, L.J.; Aiello, R.J. 1987. Effects of dietary calcium and age on parathyroid hormone, calcitonin and serum and milk minerals in the periparturient dairy cow. Journal of Nutrition 117: 201-207.

Stevenson, M. A.; Williamson, N. B.; Hanlon, D. W. 1999. The effects of calcium supplementation of dairy cattle after calving on milk, milk fat and protein production, and fertility. New Zealand Veterinary Journal 47: 53-60.

Thilsing-Hansen, T.; Jorgensen, R.J. 2001. Prevention of parturient paresis and subclinical hypocalcemia in dairy cows by zeolite A administration in the dry period. Journal of Dairy Science 84: 691-693. 